\title{
Sistem Manajemen Kesenian Jaran Kepang Turonggo Mudo Ngesti Budaya Kabupaten Semarang Sebagai Upaya Eksistensi Seni Tradisi
}

\author{
Laura Andri Retno M \\ Fakultas Ilmu Budaya, Universitas Diponegoro \\ lauraandry79@gmail.com
}

\begin{abstract}
The material object in this study is the jaran kepang Turonggo Mudo Ngesti Budaya art group located in Semarang Regency. Using the arts management theory and qualitative research methods and in-depth interviews, this study aims to analyze the management system used in the arts group. The data acquisition supports the results of the research, in the form of (1) the planning stage, consisting of weekly, monthly, and incidental work programs carried out by the Turonggo Mudo Ngesti Budoyo art group; (2) organizing stage is the activity of sorting work according to organizational structure and fostering members; (3) the stage of supervision / controlling ,consisting of the introduction, implementation and saving back, and (4) the evaluation stage, namely the stage of evaluation of the success or failure of the activities carried out by the art group. Of the four stages carried out it can be said that the Turonggo Mudo Ngesti Budaya group is a traditional arts group with a good management system, even though the process of regeneration and financial management is not optimal enough, because there is no separation of leaders on the artistic and production sides, even though the selection and management of the right management will make traditional arts groups are more optimal in existence.
\end{abstract}

Keywords: Management; existence; artistry; traditional; jaran kepang.

\section{Intisari}

Objek material pada penelitian ini adalah kelompok kesenian jaran kepang Turonggo Mudo Ngesti Budaya yang terletak di Kabupaten Semarang. Dengan menggunakan teori manajemen kesenian dan metode penelitian kualitatif serta wawancara mendalam, penelitian ini bertujuan menganalisis sistem manajemen yang digunakan pada kelompok kesenian tersebut. Pemerolehan data mendukung hasil penelitian, berupa (1) tahap perencanaan (planning), terdiri atas program kerja mingguan, bulanan, dan insidensial yang dilakukan oleh kelompok kesenian Turonggo Mudo Ngesti Budoyo; (2) tahap pengroganiasian (organisazing), merupakan kegiatan pemilahan pekerjaan sesuai struktur organiasasi dan pembinaan anggota; (3) tahap pengawasan/pengendalian (controlling, terdiri atas pendahuluan, pelaksanaan dan uimpan balik; serta (4) tahap evaluasi (evaluating) yaitu tahap penilaian tentang berhasil tidaknya kegiatan yang dilakukan oleh kelompok kesenian tersebut. Dari empat tahapan yang dilakukan maka dapat dikatakan bahwa kelompok Turonggo Mudo Ngesti Budaya merupakan kelompok kesenian tradisional dengan sistem manajemen yang baik. Meskipun pada proses regenerasi dan manajemen keuangan tidaklah cukup maksimal. Hal ini disebabkan karena tidak adanya pemisahan pimpinan pada bagian artistik maupun produksi. Padahal pemilihan dan pengelolaan manajemen yang tepat akan menjadikan kelompok seni tradisi lebih optimal dalam bereksistensi.

Kata kunci : Manajemen; eksistensi; kesenian; tradisional; jaran kepang. 


\section{Pendahuluan}

Kebudayaan merupakan perilaku manusia yang berkaitan dengan kepercayaan, ilmu pengetahuan, adat istiadat, kesenian, serta kebiasaan yang didapat dari hasil berinteraksi dengan manusia lain. Kebudayaan dapat juga diartikan sebagai warisan sejarah bersifat tradisional, seperti tradisi, tarian, musik, senjata, bahasa, dan sebagainya. Seni tradisi adalah bagian kebudayaan yang digunakan sebagai alat oleh manusia untuk mengekspresikan rasa keindahan dari dalam jiwa. Seni tradisi juga membawa pesan dari masyarakat pemiliknya berupa pengetahuan, gagasan, kepercayaan, nilai serta norma. Ciri khas yang dimiliki seni tradisi yaitu berkembang secara turun temurun, mempunyai unsurunsur kepercayaan serta interpretasi tradisi dari masyarakatnya. Tradisi dan kesenian yang tinggal atau terdapat di suatu daerah, maka ia menjadi milik dari daerah tersebut (Sedyawati, 1981:15).

Globalisasi yang terjadi di seluruh penjuru tanah air selain memberikan efek positif ternyata juga berdampak negatif pada dunia kesenian. Masyarakat cenderung tertarik pada budaya baru yang bersifat instant, mewah, hingar bingar, mengikuti trend dan lebih bergengsi. Kondisi ini mengakibatkan kesenian tradisional cenderung di pandang sebelah mata. Kurangnya perhatian pemerintah terhadap kelompok-kelompok seni tradisi memaksa mereka lebih mandiri dan kreatif untuk tetap bisa bertahan dan bereksistensi di tengah kondisi yang tidak pasti. Untuk itu kelompok seni tradisi harus memiliki gagasan atau alternatif yang kreatif. Selain menjalin relasi yang baik dengan pemerintah, faktor pendukung lain yang sangat penting justru berkaitan dengan sistem manajemen. Menurut Anton Anthoillah, manajemen merupakan kata bentukan dari "to manage” yang artinya mengatur, mengurus, atau mengelola. Sehingga dapat diartikan bahwa manajemen adalah makna unsur-unsur kegiatan yang cenderung bersifat pengelolaan (2010:13). Sistem manajemen merupakan bagian pengelolaan yang tidak dapat dipisahkan dalam sebuah organisasi.

Penelitian dengan objek kelompok jaran kepang ini menggunakan teori manajemen kesenian yang berkiatan dengan tahapan, berupa :

- Perencanaan (planning), merupakan bagian dasar dalam sistem manajemen. Pelaksanaan manajemen sangat bergantung pada bagaimana perencanaan tersebut dibuat.

- Pengorganisasian (organizing), bagian ini bertugas memastikan bagaimana 
kemampuan anggota dalam organisasi secara optimal dapat dimanfaatkan.

- Pengawasan (controlling), merupakan tahap yang berisi pengawasan tanggung jawab telah dilakukan dengan baik dan sesuai dengan aturan dalam kelompok kesenian tersebut.

- Evaluasi (evaluating), lebih mengarah pada penilaian penyebab berhasil tidaknya sebuah kegiatan. Nantinya dapat digunakan untuk bahan pertimbangan dalam pelaksanaan kegiatan-kegiata yang akan dilakukan (Lathief, 2009:14).

Sayangnya tidak semua kelompok seni mengerti dan paham tentang fungsi manajemen seni tradisional. Sebagian besar dari mereka malah tidak memiliki bentuk manajemen yang baik untuk pengembangan kelompok seninya. Pada kondisi ini perlu dilakukan pengenalan tentang sistem manajemen sebagai alat pengontrol baik dari sisi pengelolaan, pengendalian, pengawasan, dan lainnya. Manajemen yang baik dalam kelompok seni tradisi akan dapat mengurangi kecurangan yang dapat terjadi di masingmasing bagian.

Sistem manajemen dapat pula membantu pemimpin kelompok kesenian mengambil suatu keputusan yang berkaitan dengan pelaksanaan kegiatan. Selain itu pembagian tugas, jalannya proses kreatif dan pembagian honor anggota juga dapat dikendalikan dan diawasi demi eksistensi kelompok seni tradisi. Hal inilah yang menyebabkan penulis tertarik untuk meneliti kelompok kesenian jaran kepang Turonggo Mudo Ngesti Budaya (selanjutnya disingkat menjadi TMNB). Bagaimana sistem manajemen yang dipakai sebagai upaya eksistensi di tengah arus perubahan global yang semakin kuat.

Penelitian ini bertujuan untuk meningkatkan kembali kesadaran masyarakat akan perlunya manajemen dalam kelompok seni tradisi mereka.. Selain itu penelitian juga bertujuan memberikan pengetahuan tentang pengoptimalan teknik pengorganisasian dalam suatu kelompok seni Jika upaya ini dilakukan dengan baik maka nantinya selain budaya tradisi dapat lestari, kelompok jaran kepang $T M N B$ dapat mengalami peningkatan penghasilan tambahan karena tawaran pementasan kesenian tradisional menjadi lebih banyak.

Berdasarkan penelitian sebelumnya, belum ada studi yang membahas sistem manajemen di kelompok seni jaran kepang $T M N B$. Sedangkan penelitian yang hampir sama adalah penelitian yang dilakukan oleh Andi Mustajab (2013) yang berjudul Sistem 
Manajemen Sanggar Seni Ambarala Kecamatan Bungoro Kabuoaten Pangep. Hasil penelitiannya mengarah pada langkah-langkah manajemen yang dilakukan oleh sanggar tersebut. Hal ini berkaitan dengan sistem perencanaan, pengendalian, pengawasan, evaluasi dan perekrutan anggota serta kendala-kendala yang dihadapi dalam pelaksanaan sistem manajemen.

\section{Metode Penelitian}

Penelitian ini menggunakan pendekatan naturalistik dengan metode kualitatif. Pendekatan tersebut lebih fokus pada pengambilan data secara alamiah untuk menjalin kedekatan emosional antara peneliti dengan objek materialnya. Penelitian ini difokuskan pada kelompok kesenian TMNB Desa Gebang Kecamatan Bringin Kabupaten Semarang.

Pengumpulan data dilakukan menggunakan teknik wawancara mendalam dengan pertanyaan terperinci.. Selain itu, dilakukan juga pengamatan (observasi), dokumentasi dan kepustakaan.

\section{Hasil dan Pembahasan}

\section{Sekilas tentang Kelompok Kesenian Jaran Kepang Turonggo Mudo Ngesti Budoyo}

Kesenian jaran kepang merupakan bagian dari seni tradisional yang memiliki persebaran cukup luas. Awalnya hampir semua daerah di Jawa Tengah dan Jawa Timur memiliki kelompok seni berjenis jaran kepang ini. Namun sejak adanya pengaruh globalisasi, kondisi tersebut berubah. Beberapa komunitas atau paguyuban mengalami mati suri bahkan hilang sama sekali. Hanya beberapa saja dari mereka yang masih bertahan tetap eksis. Salah satuya adalah kelompok seni jaran kepang Turonggo Mudo Ngesti Budaya (TMNB).

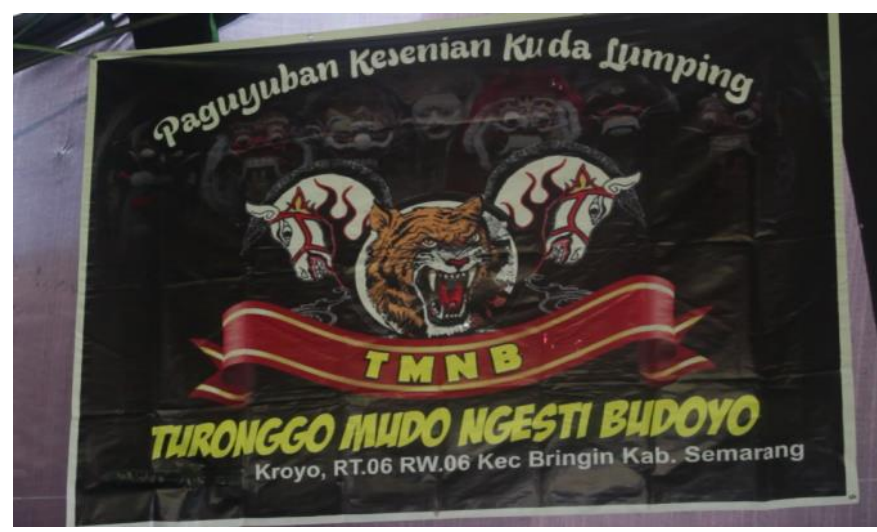

(dok. Florencia, Ira, dkk, 2019) 
$T M N B$ lahir dan berkembang di Desa Gebang, Bringin Ungaran Kabupaten Semarang sejak bulan Februari tahun 2017 atas ide salah satu anggota masyarakat bernama pak Iwan. Pak Iwan ini selanjutnya menjadi pimpinan kelompok tersebut. Berawal dari rasa cinta pada seni tradisi ditambah dengan pengalamannya pernah menjadi anggota kelompok reog Nalirojo, pak Iwan mulai membentuk kelompok kesenian sendiri dengan mengajak kelompok tari leak dari Putra Rangga yang pada saaat itu hanya mengamen saja.

Kelompok seni bentukan pak Iwan selanjutnya diberi nama Turonggo Mudo Ngesti Budoyo. Turonggo dalam Bahasa Indonesia memiliki arti kuda, Mudo artinya muda, Ngesti memiliki rmakna upaya batiniah yang didasari dengan permohonan kepada Tuhan YME sedangkan Budoyo berarti budaya. Bergabungnya kelompok kesenian Putra Rangga dengan $T M N B$ menjadikan bentuk tarian kelompok ini lebih beragam tidak hanya sebatas pada jaran kepang saja. Pertunjukan mulai dikemas lebih variatif serta memiliki pengklasifikasian pelaku dalam pertunjukannya. Jaran kepang yang ditarikan laki-laki, baik remaja maupun dewasa disebut Panaragan, sedangkan yang ditarikan perempuan disebut Kuda Pesisiran.

Anggota TMNB awalnya berjumlah 35 orang kemudian bertambah menjadi 100 orang. Sistem regenerasi belum maksimal dimiliki kelompok ini karena usainya masih tergolong baru dan anggotanya banyak yang masih berusia muda. Kesadaran yang tinggi akan pentingnya melestarikan kesenian jaran kepang menjadi salah satu faktor penting dalam perkembangannya. Meskipun tergolong komunitas baru, TMNB telah terregister sebagai kelompok seni tradisional di Dinas Kebudayaan dan Pariwisata Kabupaten Semarang.

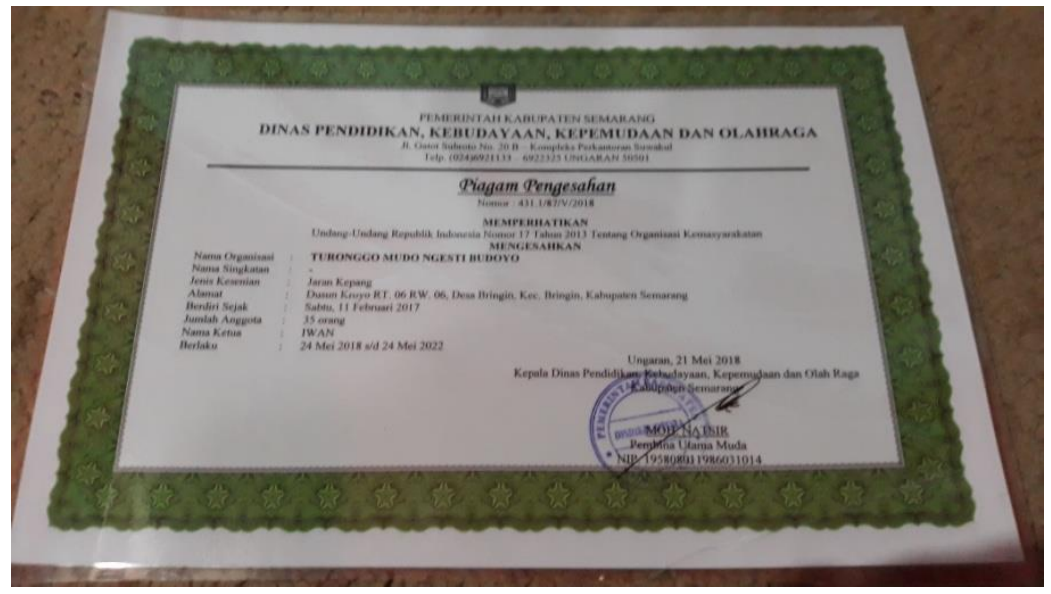

(dok. Florencia, Ira, dkk, 2019) 


\section{Sistem Manajemen Kelompok Kesenian Turonggo Mudo Ngesti Budaya Perencanaan (Planning)}

Pengelolaan dalam sebuah kelompok seni harus didasari pada sistem perencanaan terlebih dahulu. Perencanaan tersebut adalah sebuah awalan sebelum dilakukannya pengorganisasian, pergerakan serta pengawasan. TMNB memiliki sistem perencanaan yang cukup baik. Perencanaan tersebut dibuat dan digunakan untuk panduan dalam menyusun program kerja mingguan, bulanan dan insidental sesuai dengan visi misi kelompok tersebut.

Program kerja mingguan lebih mengarah pada program kerja untuk pengurus dan anggota yang dilakukan rutin tiap minggunya. Program ini meliputi :

a. latihan rutin yang dilakukan terjadwal tiap hari minggu selepas dhuhur dengan durasi waktu 4-5 jam bertempat di pelataran rumah Pak Iwan. Karena anggotanya rata-rata anak-anak hingga remaja, maka dipilihlah hari libur untuk jadwal latihan. Saat bulan puasa latihan tersebut dihentikan supaya anggota dapat lebih fokus beribadah. Pelatih tarian selain oleh pak Iwan juga kadang berganti dengan Pak Fatoni seorang guru kesenian yang tinggal di daerah Ungaran. Latihan ini ditujukan untuk mengasah kemampuan gerak koreografi. Baik pengurus maupun anggotanya aktif mengikuti latihan tersebut. Takjarang waktu latian berakhir sampai malam. Bagi masyarakat sekitar, kondisi ini tidak menjadi soal, mereka tidak merasa terganggu. Justru masyarakat antusias mendukung keberadaan TMNB karena dianggap sebagai kegiatan pelestarian budaya serta aset atau kekayaan daerah.

b. Perawatan properti baik alat musik maupun kostum juga dilakukan rutin tiap minggunya. Properti juga digunakan dalam latian rutin sebagai media pendukung, sehingga setelah selesai latihan dilakukan pengecekan dan perawatan. Alat musik yang digunakan sebagai pengiring tarian $T M N B$ adalah musik gamelan. Penari menggunakan pakaian yang berbeda-beda tergantung tahapan tari apa yang ditampilkan. Untuk durasi pementasan itu sendiri tergantung pada yang memiliki hajatan. Apakah sehari semalam atau hanya beberapa jam saja. Namun biasanya jika undangan pementasan diperoleh dari dinas maka waktu tampilnya hanya sekitar 15 menit saja,. Pemain yang akan pentas dipilih oleh pelatih berdasarkan tingkat kompetensinya. 
c. Evaluasi merupakan bagian akhir dalam latihan. Para anggota kelompok TMNB akan berkumpul untuk melakukan review terhadap proses latian. Hal ini dilakukan untuk mengukur perkembangan kemampuan masing-masing anggota. Evaluasi dipimpin oleh pelatih sekaligus ketua $T M N B$. Tak jarang hal-hal lain yang sifatnya non teknis seperti kesediaan properti atau persiapan pementasan dibahas pula dalam evaluasi tersebut.

Program kerja bulanan $T M N B$ terdiri dari rapat rutin pengurus dan inventarisasi alat. Rapat rutin dipimpin oleh ketua, serta dihadiri oleh bendahara, sekretaris sebagai bagian dari tim produksi dan beberapa anggota dari tim artistik. Laporan keuangan rutin disampaikan pada tiap bulannya. Namun karena belum memiliki model pembukuan dan pencatatan yang maksimal maka laporan tersebut masih berbentuk laporan sederhana. Selain itu pembahasan tentang keanggotaan baik pasif maupun aktif juga dilakukan. Nantinya akan menjadi bahan evaluasi tentang sistem rekruitmen di setiap akhir tahunnya. Anggota yang pasif hadir latihan akan diberi perhatian khusus supaya kembali aktif bergabung lagi di kelompok tersebut. Inventarisasi properti lebih bersifat pada pencatatan ulang dan pengecekan kondisi. Jika dirasa properti yang digunakan mengalami kerusakan maka bendahara akan mengeluarkan anggaran untuk biaya perbaikan atau pembelian kostum atau alat yang baru.

Program kerja insidental merupakan program kerja yang dilakukan oleh TMNB guna membahas hal-hal yang bersifat darurat, misalnya pertemuan terkait permintaan pentas dadakan. Tentu saja persiapan dan koordinasi tim sangat diperlukan secepatnya sehingga rapat insidental harus dilakukan. Selain itu jika kelompok kesenian ini memiliki permasalahan-permasalahan seperti reschedule jadwal latihan karena banyaknya anggota yang tidak bisa hadir di waktu yang telah ditentukan. Maka dibutuhkan pencarian solusi secepatnya melalui pertemuan insidental. Sehingga nantinya tujuan bersama dalam kelompok tersebut dapat dicapai.

\section{Pengorganisasian (Organisazing)}

Pengorganisasian dalam $T M N B$ merupakan sistem pembagian kerja dan penugasan yang sifatnya lebih spesifik. Masing-masing bagian memiliki beban tanggung jawab yang berbeda. Pengorganisasian ini dilakukan supaya kemampuan sumber daya manusia yang ada pada $T M N B$ dapat digunakan secara optimal. Organisasi dalam kelompok seni ini telah 
memiliki terstruktur dengan baik. Hal ini ditunjukkan dengan adanya susunan organisasi meliputi ketua, sekretaris, bendahara, serta seksi-seksi yang saling melengkapi satu sama lain.

Sayangnya tidak ada pemisahan yang jelas antara tim produksi (ketua, bendahara, sekretaris) dengan tim produksi (seksi latihan, musik, properti). Tim produksi lebih fokus pada pekerjaan administratif sedangkan tim artistik tangung jawabnya terpusat pada penyelenggaraan pementasan. Kondisi riil di $T M N B$, pimpinan kelompoknya sekaligus merangkap sebagai pelatih. Hal ini meyebabkan konsentrasi terpecah dan sistem kerja tidak maksimal. Beberapa anggota yang masuk dalam tim produksi merangkap juga di tim artitistik. Pembagian kerja yang tidak efisien ini jelas akan berpengaruh pada hasil pementasan yang mereka tampilkan.

Pembinaan anggota dalam TMNB merupakan bagian dari sistem pengorganisasian. TMNB memiliki anggota yang cukup banyak. Dilihat dari masa aktifnya, anggota tersebut terbagi menjadi dua, yaitu anggota lama dan anggota baru. Supaya pembinaannya berjalan lebih efektif maka perlu dicarikan solusi berkaitan dengan sistem latihan dan waktu pementasan. Hal ini dimaksudkan agar anggota baru juga memiliki kesempatan yang sama dengan anggota lama. Dalam teknis latihan, anggota baru berlatih bersama dengan anggota lama. Hal ini dipandang cukup efektif supaya anggota baru dapat menerima masukan-masukan yang berkaitan dengan olah gerak atau koreografi. Selain itu, anggota baru dapat ikut praktik langsung melihat penampilan dari anggota lama. Nantinya diharapkan regenerasi dapat terlaksana dengan baik dan kesenjangan kemampuan koreografi antara dua anggota tersebut tidak terpaut jauh.

\section{Pengawasan/pengendalian (Controlling)}

Tahap ini merupakan bagian yang fokus pada kegiatan mengendalikan atau mengawasi ekerjaan dan tanggung jawab pengurus serta anggota apakah telah berjalan baik sesuai rencana atau tidak. Tahapan pengawasan yang dilakukan pengurus TMNB untuk menemukan permasalahan, antara lain:

a. Tahap pendahuluan

Tahap pendahuluan dilakukan untuk mengantisipasi masalah sedini mungkin. Pengurus TMNB menggunakan pendekatan yang bersifat persuasif terhadap 
anggotanya, sehingga tercipta komunikasi yang baik. Komunikasi ini berfungsi untuk mengetahui kebutuhan dari masing-masing anggotanya. Misalnya, pengawasan terhadap penyediaan peralatan, konsumsi, kostum sebelum latihan.

b. Tahap pelaksanaan

Tahap pelaksanaan dilakukan untuk mengawasi proses pelaksanaan program kerja, diantaranya administrasi keuangan, pengawasan saat latihan sampai dengan selesainya pementasan. Pada proses ini membutuhkan perhatian yang sangat besar karena sukses atau tidaknya sebuah kegiatan berjalan pada tahap ini.

c. Tahap umpan balik

Tahap umpan balik merupakan kegiatan evaluasi yang berkaitan dengan sistem kerja anggota. Tahap ini berisi jajak pendapat. mengajak anggota perperan aktif memberikan pendapatnya tentang kegiatan yang sudah berjalan termasuk kendala yang dihadapi saat pelaksanaan kegiatan. Sehingga nantinya diharapkan semua masalah dapat diselesaikan dan menjadi pengalaman dan pembelajaran yang baik bagi semua anggotanya. Setiap organisasi akan berhasil apabila di dalam organisasi tersebut memiliki suasana kerja yang kondusif antara pengurus dan anggotanya.

Pimpinan kelompok $T M N B$ dan semua pengurus bersedia terjun langsung ke lapangan untuk secara aktif melakukan pengawasan semua proses kegiatan. Para anggota baik lama maupun baru semangat dalam mengikuti latihan. Hal ini menjadi modal penting dalam proses eksistensi kelompok seni tradisi. Pementasan yang didukung oleh koreografi, musik iringan, dan kostum yang menarik membuat TMNB sering mendapat undangan untuk tampil baik di acara dinas, hajatan, festival, maupun kegiatan masyarakat lainnya. Selain itu semangat kemajuan dan kebersamaan para anggotanya menjadi salah satu faktor pendukung bekembangnya kelompok seni $T M N B$ ini.

Meski memiliki keterbatasan, kelompok ini tetap bertahan dan bereksistensi dengan menerapkan sistem manajemen yang baik untuk mengetahui faktor pendunkung dan penghambatnya. Sistem perencanaan yang meliputi :

- Penyusunan program kerja baik mingguan, bulanan, maupun insidental.

- Pembagian tanggung jawab yang jelas antara pengurus dan anggota.

- Pencatatan dan pembukuan keuangan yang dilaporkan pada setiap bulan meskipun masih sederhana.

- Pengawasan yang secara rutin dilakukan tiap bulannya. 
Faktor pendukung lain yang berguna untuk perkembangan kelompok seni ini juga diperoleh dari Pemerintah Kabupaten Semarang. Adanya petugas khusus (pamong budaya) di setiap kecamatan untuk melakukan pengawasan dan pembinaan terhadap kelompok kesenian. Event-event pertunjukan kesenian juga hampir setiap bulan dilaksanakan sehingga membuat kegiatan kesenian di Kabupaten Semarang menjadi lebih semarak. Selain itu perhatian pemerintah terlihat pada penganggaran APBD Kabupaten Semarang senilai Rp 2.000.000.000,- per tahun untuk bantuan inventaris kelompok kesenian seperti kostum ataupun alat musik. Bantuan ini merupakan stimulant atau rangsangan bagi kelompok kesenian untuk lebih berkembang dan melestraikan nilai budaya bangsa.

\section{Evaluasi (Evaluating)}

Evaluasi merupakan tahap penilaian kegiatan yang digunakan untuk mengukur berhasil tidaknya suatu kegiatan. Berdasarkan data yang diperoleh, kelompok kesenian jaran kepang $T M N B$ selalu melakukan evaluasi di setiap akhir kegiatan atau latihan. Hal ini dilakukan supaya masalah-masalah ataupun kendala dapat diselesaikan. Selain itu, peningkatan kinerja pengurus juga tidak lepas dari kegiatan evaluasi supaya peningkatan kinerja pengurus dan peningkatan kemampuan anggota dapat tercapai. Karena kelengahan pengurus baik tim produksi maupun artistik dalam menyiapkan sarana dan prasarana dapat menjadi faktor ketidakpuasan pihak luar yang mengundang kelompok ini.

Evaluasi maupun pembinaan tidak hanya dilakukan oleh pengurus saja. Pemerintah Kabupaten Semarang juga sering melakukan pembinaan terhadap kelompokkelompok kesenian yang ada di wilayahnya melalui pamong budaya. Selain itu, peran organisasi FK Metra (Forum Komunikasi Media Tradisional) dalam sistem evaluasi manajemen kesenian di tingkat kabupaten Semarang jelas sangat membantu. Kehadiran FK Metra membuat kelompok kesenian menjadi lebih terorganisir, khususnya kelompok kesenian $T M N B$.

FK Metra sebagai wadah informasi bagi kelompok kesenian tradisional mempunyai tujuan sebagai sarana hiburan, pendidikan, kontrol sosial, pelestarian dan pengembangan budaya. Unsur dari lembaga ini adalah organisasi kelompok kesenian, manajemen sistem pengelolaan, tenaga pelaksana dan modal kerja. Lembaga ini juga 
memfasilitasi pertunjukan di depan umum yang mengandung informasi dan pelestarian kebuadayaan

\section{Simpulan}

Indonesia adalah negara dengan banyak suku bangsa. Tiap suku memiliki corak budaya yang beraneka. Keanekaragaman suku menjadikan Indonesia kaya akan kebudayaan dan kesenian. Kesenian jaran kepang merupakan salah satu bagian dari kebudayan tradisional. Kelompok-kelompok kesenian jaran kepang tersebar di beberapa tempat di Jawa Tengah. Salah satu kelompok tersebut bernama Turonggo Mudo Ngesti Budaya yang terletak di Kabupaten Semarang. Pada hasil penelitian dapat diketahui bahwa Turonggo Mudo Ngesti Budaya merupakan kelompok kesenian tradisional dengan sistem manajemen yang baik. Akan tetapi pada proses regenerasi dan manajemen keuangan tidaklah cukup maksimal. Salah satu penyebabnya karena tidak adanya pemisahan pimpinan dalam artistik maupun produksi. Padahal pemilihan dan pengelolaan manajemen yang tepat akan menjadikan kelompok seni tradisi lebih optimal dalam bereksistensi

\section{Daftar Pustaka}

Anthoillah, Anton.2010. Dasar-Dasar Manajemen.Bandung: Pustaka Setia.

Florencia, Ira. 2019. "Kesenian Tradisional Jaran Kepang dari Komunitas Turonngo Mudo Ngesti Budaya di Kabupaten Semarang," Tugas Mata Kuliah Kesenian Tradisional Program Studi Sastra Indonesia, Fakultas Ilmu Budaya Universitas Diponegoro.

Latief, Halilintar. 2009. Sanggar Seni. Makassar: Padat Daya

Mustajab, Andi. 2013. "Sistem Manajemen Sanggar Seni Ambarala Kecamatan Bungaro Kabupaten Pangep," Skripsi Program Studi Pendidikan Sendratasik Fakultas Seni dan Desain Universitas Negeri Makasar.

Sedyawati, Edi. 1981. Pertumbuhan Kesenian Tradisional. Jakarta: Sinar Harapan. 